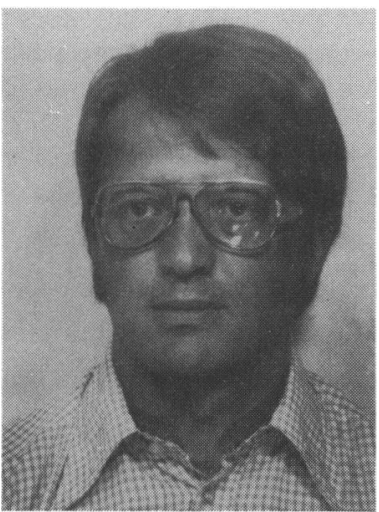

M. Pääkkönen

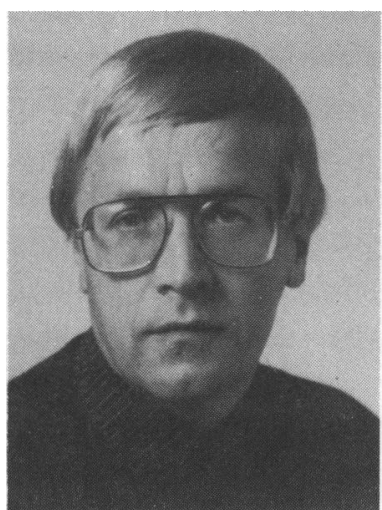

E. M. Alhava

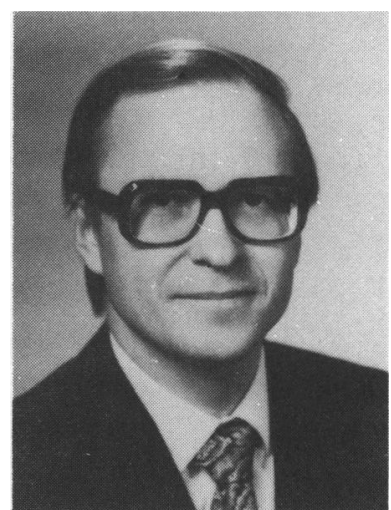

O. Hänninen

\title{
EFFECT OF TOURNIQUET ISCHAEMIA ON MUSCLE ENERGY METABOLISM IN MENISCECTOMY PATIENTS
}

\author{
M. PÄÄKKÖNEN, MD, E. M. ALHAVA, MD and O. HÄNNINEN, MD, PhD \\ Departments of Surgery and Physiology, University of Kuopio and Kuopio Institute of Exercise Medicine, \\ Kuopio, Finland
}

\begin{abstract}
The enzyme levels of muscle energy metabolism were studied in eight male meniscectomy patients before and 10 minutes after release of the tourniquet and on the third post-operative day. The average tourniquet time was $65.1 \mathrm{~min}$. The muscle samples were taken from the vastus lateralis muscles; the healthy side served as the control. The greatest enzyme changes $10 \mathrm{~min}$ after release of the tourniquet were the falls in succinate dehydrogenase (SDH) and creatine phosphokinase (CPK) activities, ( $p<0.01$ and $p<0.025$ respectively). On the 3rd day phosphofructokinase (FFK) and malate dehydrokinase (MDH) activities were also lowered in the tourniquet limb, but the lactate dehydrogenase (LDH) was not changed significantly.
\end{abstract}

In the control extremity only SDH showed a lowered value on the 3rd post-operative day $(p<0.05)$, perhaps due to hypokinesia in hospital.

The results indicate that even one-hour tourniquet ischaemia causes an enzyme release from muscle and for at least three days after the tourniquet enzyme activities in muscle are lowered, perhaps because of the combined effect of the tourniquet ischaemia and hypokinesia after the operation.

Key words: skeletal muscle ischaemia, tourniquet.

\section{INTRODUCTION}

As the knee joint is especially susceptible to injury in sport and as operations on knee cartilages and ligaments necessitate a bloodless field, possible harmful effects of the use of tourniquets was investigated.

\section{Correspondence to:}

0 . Hänninen,

Department of Physiology,

University of Kuopio.

POB 138 ,

SF-70101 Kuopio 10,

Finland
Providing a bloodless field, haemostasis by the pneumatic tourniquet is used universally today in orthopaedic operations upon the extremities. A two-hour tourniquet is considered to be safe in clinical use (Flatt, 1972; Stewart, 1975; Adams, 1976; Santavirta, Kauste et al, 1978). In reconstructive operations and endoprosthetic replacement of the knee joint the two hour limit is, however, often exceeded (Santavirta, Kauste et al, 1978). The muscle oxygen tension drops during the tourniquet blockade (Santavirta, Höckerstedt et al, 1978). Stock, Bohn et al (1973) found a decrease in muscle glycogen content and an increase in the muscle lactate level during tourniquet ischaemia. The $\mathrm{pH}$ of venous blood decreases from 7.40 to 6.90 after two- 
$=$ CONTROL

- $=p<0.05$

$\ldots \quad=p<0.01$
= TOURNIOUET

. $\quad=p<0.025$

*n* $=p<0.005$
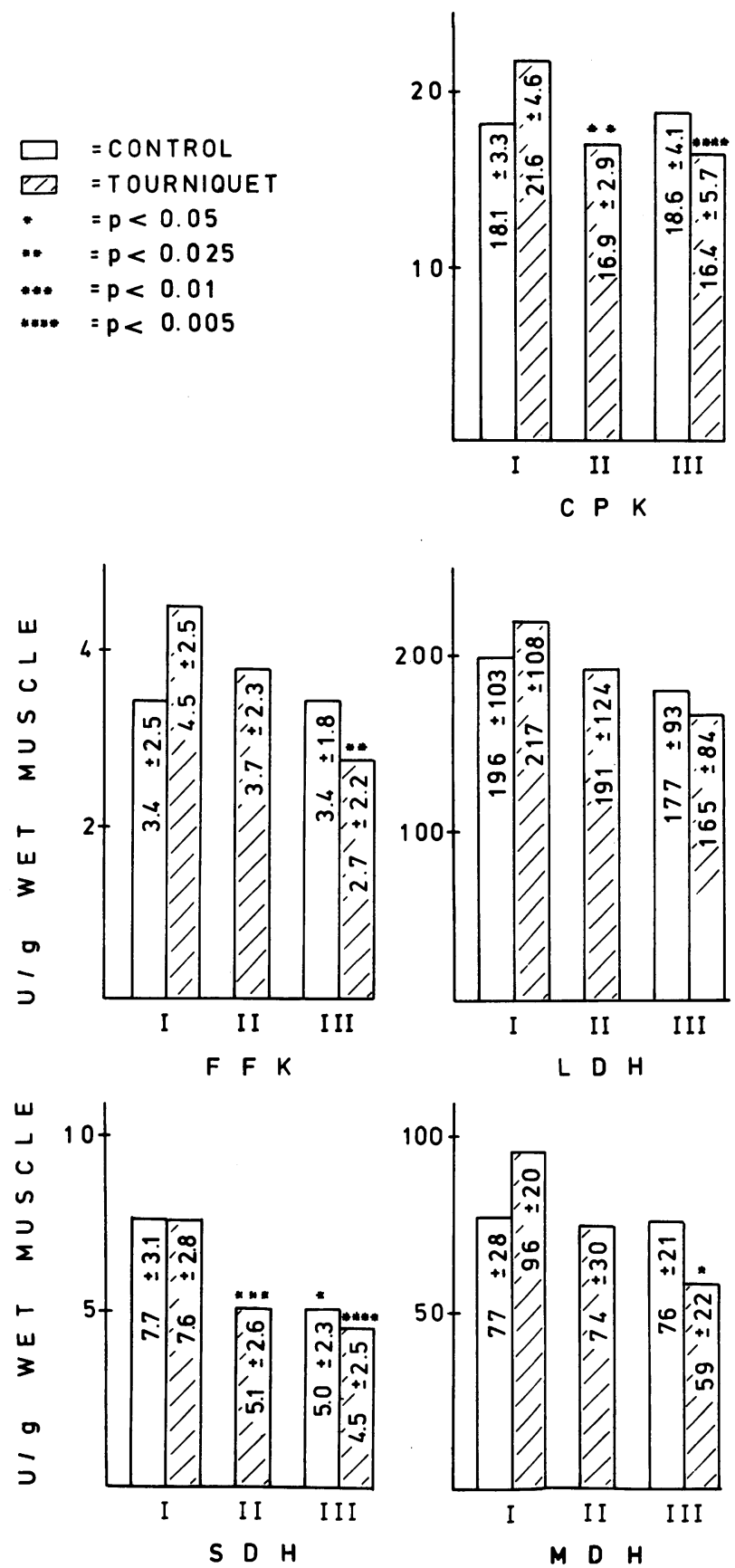

Fig. 1. The effect of tourniquet ischaemia in meniscectomy patients on the levels of energy metabolism enzymes in the vastus lateralis muscle. The unoperated leg served as a control. I = before the release of the tourniquet, $\|=10 \mathrm{~min}$. after its release, $\| I=$ on the $3 \mathrm{rd}$ postoperative day. The means and $\pm S D$ of the enzyme activities (U/g wet muscle) and the significances compared with value I are given $(n=8)$. hour tourniquet ischaemia (Wilgis, 1971). In experimental studies irreversible changes have been reported after 3-4 hour ischaemia in muscle tissue (Mäkitie and Teräväinen, 1977; Tountas and Bergman, 1977; Santavirta, Luoma et al, 1978a). Histological studies showed cell damage and changes especially in muscle mitochondria (Solonen and Hjelt, 1968; Mäkitie and Teräväinen, 1977; Tountas and Bergman, 1977). Intracellular creatine phosphokinase was released into the extracellular space in laboratory animals and in humans as a sign of ischaemic cellular damage (Chiu, Wang et al, 1976; Santavirta, Kauste et al, 1978).

In sports medicine the extent of the possible iatrogenic tissue damage is of great importance. Unfortunately there is at the moment only a limited amount of data available on the effects of meniscectomy on the glycolytic and oxidative enzymes in leg muscle in spite of the frequency of this operation.

The purpose of this study was to record the possible "wash out" phenomenon of releasing the tourniquet in the thigh muscle and the three-day post-operative course of the muscle energy metabolism in male patients subjected to meniscectomy. Phosphofructokinase (FFK), succinate dehydrogenase (SDH), malate dehydrogenase (MDH) and lactate dehydrogenase (LDH) activities were measured from biopsies of the vastus lateralis muscle. Creatine phosphokinase (CPK) activity was followed for comparison.

\section{PATIENTS AND METHODS}

Our series comprised eight male patients operated on for a ruptured meniscus in the University Central Hospital of Kuopio. The mean age of the patients was 36.1 (range 19-53) years. The operations were carried out under epidural anaesthesia.

The tourniquet was made with an Esmarch rubber bandage. It was maintained by a cuff, inflated to 350 $\mathrm{mm} \mathrm{Hg}$ (Esmarch, 1873). The cuff was situated as proximally as possible on the thigh. The average tourniquet time was $65.1 \mathrm{~min}$ (range $50.100 \mathrm{~min}$ ).

All the patients were allowed to stand up on the 1st post-operative day, but they did not use the operated leg for support during the three post-operative days. All the patients were discharged on the 3rd day.

The muscle samples were taken before exanguinating the limb, before releasing the tourniquet, 10 minutes after releasing it and finally on the 3rd postoperative day using the technique described by Bergström (1975) from the vastus lateralis muscles. The nonoperated leg served as the control in the study. The biopsy site was the margin in the middle and distal thirds of the thigh about $1 \mathrm{~cm}$ beneath the fascia. The 
samples were frozen within 10 sec. in liquid nitrogen and stored at $-80^{\circ} \mathrm{C}$ until the enzyme analyses were made.

The muscle samples were homogenised and the activities of FFK (Boström et al, 1974), SDH (Earl and Korner, 1965), MDH (Englard and Siegel, 1969), LDH and CPK (Biochemical Boehringer Mannheim, Biochemica Test Combination ${ }^{R}$, Cat. No. 15926 and 15977) were analysed as described earlier. The statistical analysis was made with Student's t-test with paired comparison.

The muscle samples were always taken by the same person and the post-operative care was the same. There were no complications in the muscle biopsies or meniscectomy operations.

\section{RESULTS}

Before the tourniquet was applied there were no differences in the enzyme activities in the vastus lateralis muscles of the patients' legs (Table I). The enzyme activities were unchanged in the operated leg before releasing the tourniquet. Ten minutes after its release the activities of SDH and CPK were significantly lower than before it $(p<0.01$ and $p<0.025$, respectively). The activities of FFK, MDH and LDH, however, were not altered significantly. On the 3rd post-operative day the CPK and SDH values were lower than 10 minutes after opening the tourniquet $(p<0.005)$. The FFK and MDH activities were also decreased on the 3rd post-operative day, but LDH activity did not change significantly during the hospitalisation time.

The activities in the control limb did not change significantly during hospitalisation with the exception of SDH which was lower than before on the 3rd postoperative day $(p<0.05)$.

\section{DISCUSSION}

In this study we found significantly decreased SDH and CPK activities in the thigh muscle distal to the "crush area" of the cuff within one hour of applying the tourniquet. This is in contrast to Tountas' and Bergman's findings in 1977 of no changes in muscle SDH activities after two hours ischaemia in man. Our results concur, however, with the elevated venous blood CPK activities (Chiu et al, 1976; Santavirta, Kauste et al, 1978) and unchanged LDH activities in humans reported earlier (Santavirta, Kauste et al, 1978). It probably requires very serious damage before enzymes like LDH escape from the muscle. This did not occur in our study. It has been reported that LDH activity is decreased significantly in rabbit's muscle after 3-4 hour ischaemia (Santavirta, Luoma et al, 1978b).

Data obtained suggest that the lowering of enzyme

\section{TABLE I}

The effect of tourniquet ischaemia in meniscectomy patients on the levels of energy metabolism enzymes in the vastus lateralis muscle. The unoperated leg served as the control. The means and \pm SD of the enzyme activities $(U / g$ wet muscle) are given $(n=8)$.

\begin{tabular}{|c|c|c|c|}
\hline Enzyme & $\begin{array}{l}\text { Before } \\
\text { release of } \\
\text { tourn. } \\
\text { (I) }\end{array}$ & $\begin{array}{l}10 \mathrm{~min} \\
\text { after the } \\
\text { release } \\
\text { (III) }\end{array}$ & $\begin{array}{l}\text { 3rd postop. } \\
\text { day } \\
\text { (III) }\end{array}$ \\
\hline tourn. & $\begin{array}{r}21.6 \pm \\
4.6\end{array}$ & $\begin{array}{c}16.9 \underset{ \pm}{ \pm} \\
2.9(x \times)\end{array}$ & $\begin{array}{c}16.4 \underset{ \pm}{ \pm .7}(x \times) \\
\end{array}$ \\
\hline $\begin{array}{l}\text { CPK } \\
\text { control }\end{array}$ & $\begin{array}{r}18.1 \pm \\
3.3\end{array}$ & - & $\begin{array}{r}18.6 \pm \\
4.1\end{array}$ \\
\hline tourn. & $\begin{array}{l}4.50 \pm \\
2.50\end{array}$ & $\begin{array}{l}3.74 \pm \\
2.30\end{array}$ & $\begin{array}{l}2.73 \pm \\
2.20(x x)\end{array}$ \\
\hline $\begin{array}{l}\text { FFK } \\
\text { control }\end{array}$ & $\begin{array}{l}3.43 \pm \\
2.50\end{array}$ & - & $\begin{array}{l}3.43 \pm \\
1.80\end{array}$ \\
\hline tourn. & $\begin{array}{l}216.7 \pm \\
108.4\end{array}$ & $\begin{array}{l}191.0 \pm \\
124.2\end{array}$ & $\begin{array}{r}164.7 \pm \\
92.8\end{array}$ \\
\hline $\begin{array}{l}\text { LDH } \\
\text { control }\end{array}$ & $\begin{array}{l}195.9 \pm \\
102.7\end{array}$ & - & $\begin{array}{r}176.6 \pm \\
83.6\end{array}$ \\
\hline tourn. & $\begin{array}{l}7.62 \pm \\
2.80\end{array}$ & $\begin{array}{l}5.10 \pm \\
2.60(x x)\end{array}$ & $\begin{array}{l}4.51 \pm \\
2.46(x x)\end{array}$ \\
\hline $\begin{array}{l}\text { SDH } \\
\text { control }\end{array}$ & $\begin{array}{l}7.65 \pm \\
3.10\end{array}$ & - & $\begin{array}{l}5.04 \pm \\
2.31(x)\end{array}$ \\
\hline tourn. & $\begin{array}{l}95.6 \pm \\
20.3\end{array}$ & $\begin{array}{l}74.4 \pm \\
30.4\end{array}$ & $\begin{array}{l}58.5 \\
21.6(x)^{ \pm}\end{array}$ \\
\hline $\begin{array}{l}\text { MDH } \\
\text { control }\end{array}$ & $\begin{array}{l}76.8 \pm \\
28.1\end{array}$ & - & $\begin{array}{l}75.9 \pm \\
20.8\end{array}$ \\
\hline
\end{tabular}

The difference compared with value $I$ is probably $(x)$ significant $(p<0.05)$ and $(x x)$ significant $(p<0.025)$.

activities in the tourniquet limb continues for at least three days after the operation. During this period FFK and MDH follow the same pattern as CPK and SDH. Thus, the muscle metabolism is disturbed for several days after meniscectomy in man, though in experimental studies with dogs, the metabolism and the membrane function of the muscle cells have returned to normal in one hour after three hours' ischaemia (Enger et al, 1978). Because there were no differences between the tourniquet and control legs before the tourniquet it seems that the ruptured meniscus itself does not influence the muscle enzyme activity before or at the time of operation.

Noteworthy are the lowered values of SDH both in 
the operated and in the control extremity on the third post-operative day, most probably due to disuse (Tomanek and Donald, 1974). The low values of enzyme activities on the 3rd post-operative day in the operated leg represent thus a result of the combined effects of tourniquet ischaemia and hypokinesia. It seems, however, that the effect of tourniquet is dominating.

Our results suggest that the tourniquet time during the operation should be minimised. The two-hour recommendation for the upper time limit appears to be too high from the metabolic point of view. Further- more, hypokinesia after the operation may accentuate the negative effects of tourniquet operation on the muscle metabolism. Both facts are of importance in sports medicine. The metabolic recovery deserves further studies.

\section{ACKNOWLEDGEMENTS}

This work was supported financially by the PohjoisSavo Fund of the Finnish Cultural Foundation. Mrs. Riitta Venäläinen's help with the assays is gratefully acknowledged.

\section{REFERENCES}

Adams, J., 1976. Standard Orthopaedic Operations. Churchill Livingstone, New York, p. 4.

Bergström, J., 1975 "Percutaneous muscle biopsy of skeletal muscle in physiological and clinical research". Scand.J. Clin.Lab.Invest. 35: 609-616.

Boström, S., Fahle, M., Hjalmarson, O. and Johanson, R., 1974 "Activities of rat muscle enzymes after acute exercise". Acta Physiol.Scand. 90: 544-554.

Chiu, D., Wang, H. and Blumenthal, M. R., 1976 "Creatine phosphokin zse release as a measure of tourniquet effect on skeletal muscle". Arch.Surg. 111: 71-74.

Earl, C. D. N. and Korner, A., 1965 "The isolation of properties of cardiac ribosomes and polysomes". Biochem.J. $94: 721-734$.

Enger, E. A., Jennische, E., Medegard, A. and Halja, H., 1978 "Cellular restitution after $3 \mathrm{~h}$ of complete tourniquet ischaemia". Eur.Surg. Res. 10: 230-239.

Englard, A. and Siegel, L., 1969 "Malate dehydrogenase". In Lowstein J. M. (Ed.) Methods in enzymology, Academic Press, New York and London, pp. 99-106.

Esmarch, J., 1873 "Über künstliche Blutleere bei Operationen". Sammlung klinische Vorträge in Verbindung mit deutschen Klinikern. Chirurgie 19: 373.

Flatt, E. A., 1972 "Tourniquet time in hand surgery". Arch.Surg. 104: 190-192.

Mäkitie, J. and Teräväinen, H., 1977 "Ultrastructure in striated muscle of the rat after temporary ischaemia". Acta Neuropathol. 37: 237-245.

Santavirta, S., Höckerstedt, K. and Niinikoski, J., 1978 "Effect of pneumatic tourniquet in muscle oxygen tension". Acta Orthop.Scand. 49: 415-419.

Santavirta, S., Kauste, A. and Rindell, K., 1978 "Tourniquet ischaemia. Clinical and biochemical observations". Ann. Chir.Gynaecol. 67: 1-4.

Santavirta, S., Luoma, A. and Arstila, A., 1978a "Ultrastructural changes in striated muscle after experimental tourniquet ischaemia and short reflow". Eur.Surg. Res. 10:415-424.

Santavirta, S., Luoma, A. and Arstila, A., 1978b "Morphological and biochemical changes in striated muscle after experimental tourniquet ischaemia". Res.Exp.Med. 76: 1-7.

Solonen, K. and Hjelt, L., 1968 "Morphological changes in striated muscles during ischaemia". Acta Orthop.Scand. 39: 13-19. 
Stewart, J., 1975 "Tourniquets". In: Traction and Orthopaedic Appliances. Churchill Livingstone, New York, p. 181.

Stock, W., Bohn, H. J. and Isselhard, W., 1973 “Die Restitution des Energiestoffwechsels der Skeletmuskulatur der Ratte nach langdauernder Ischämie". Res. Exp.Med. 159: 306-320.

Tomanek, R. and Donald, D., 1974 "Degeneration of different types of skeletal muscle fibres by immobilisation". J.Anat. 118: 531-541.

Tountas, C. P. and Bergman, R. A., 1977 "Tourniquet ischaemia: Ultrastructural and histochemical observations of ischaemic human muscle and of monkey muscle and nerve". J.Hand.Surg. 2: 31-37.

Wilgis, E. F. S., 1971 "Tourniquet ischaemia". J.Bone Joint Surg. 53-A: 1333-1346.

BOOK REVIEW

Title: SPORTS FITNESS AND SPORTS INJURIES

Editor:

T. Reilly

Publisher:

Faber and Faber (London), 1981

Price: $\mathbf{6 9 . 9 5} 298$ pages. Index. Ch. 37. Figs. 146

(Hard cover also available - price unknown)

26 Contributors

Following a foreword by Dick Jeeps, Chairman of the Sports Council, the first part of this book is concerned with the physical and mental health of the athlete, with contributions from the Editor and his colleagues at Liverpool Polytechnic, and Surgeon Rear Admiral Stanley Miles, who was Post-Graduate Dean in the Faculty of Medicine, University of Manchester, at the time the first Symposium took place. This book is based upon several interdisciplinary meetings. D. Markham, a Manchester orthopaedic surgeon, also contributes to this section.

The second section is devoted to training - weight training, for strength, injury prevention, flexibility, followed by two sections on injuries in specific sports - team games and individual events, and these included a brief description of baseball, and "grid-iron" football, unfamiliar to most UK readers, and an excellent account of subaqua hazards.

The fifth section on orthopaedic injuries, starts with an account of the physiology of injured muscle by R. J. Maughan, the Aberdeen physiologist, and continues with a well illustrated account of the spine, its anatomy and its injuries by Duncan Troup. In a smiliar way Lisle Thompson deals with the shoulder, elbow, pelvis and thigh, and J. N. Rimmer with the wrist and fingers: though he gives details of some of the less common wrist injuries, the common Colles' fracture is omitted altogether! lan Adams discusses acute knee injuries from a practical point of view, without going into details of chronic instability, pes anserinus transplants, etc., the field of the specialist. He also discusses injuries to the ankle region, including the Achilles tendon.

The final section covers the immediate assessment of injury (Leon Walkden), first-aid (Tony Fowler), physiotherapy (Val Steele), fitness testing after injury (Dennis Wright) and rehabilitation (Barry Maddox).

All too often, in a multi-author book there is multi-standard of Chapters, but not in this book, where the standard is uniformly high. The figures, mostly drawn by one artist, are excellent, and the half-tone photographs, electron microscopy and radiographs all illustrate their points clearly.

The book is compiled from papers given at several interdisciplinary symposia held at Liverpool Polytechnic, but the careful editing gives an overall view of the medical and biological aspects of a wide variety of sports, that must be of value not only to the general practitioner, physiotherapist and sports scientist, but also to the expert who can add his own specialised knowledge to the general and wide ranging material given within.

H. E. Robson 